\title{
IMPLEMENTASI KEBIJAKAN TINDAK LANJUT HASIL PEMERIKSAAN KEUANGAN NEGARA DALAM PENYELENGGARAN JAMINAN KESEHATAN NASIONAL
}

\author{
Sri Haryati ${ }^{1}$, Bahrullah Akbar ${ }^{2}$, Khasan Effendy ${ }^{3}$, Sampara Lukman ${ }^{4}$ \\ ${ }_{1,2,3,4}$ Institut Pemerintahan Dalam Negeri (IPDN) \\ Email: lilyranggi@yahoo.com
}

\begin{abstract}
Abstrak
Tujuan penelitian ini adalah untuk menganalisis implementasi kebijakan tindak lanjut hasil pemeriksaan keuangan negara dalam penyelenggaraan Jaminan Kesehatan Nasional. Penelitian menggunakan pendekatan penelitian kualitatif. Pengumpulan data dilakukan dengan menggunakan teknik wawancara, observasi dan studi dokumentasi. Analisis data dilakukan secara deskriptif dengan analisis triangulasi para pengamat. Hasil penelitian menemukan bahwa pelaksanaan tindak lanjut hasil pemeriksaan tersebut belum sepenuhnya efektif, karena 5 dari 26 rekomendasi yang sudah ditindaklanjuti oleh BPJS Kesehatan belum sesuai dengan rekomendasi Badan Pemeriksa Keuangan. Implementasi kebijakan tindak lanjut hasil pemeriksaan keuangan negara dalam penyelenggaraan Jaminan Kesehatan Nasional meliputi tindakan-tindakan dan perbaikan-perbaikan yang meliputi: (1) Penetapan regulasi yang memadai terkait pengujian kebenaran data PPU BU; (2) Pendistribusian KIS yang masih berada dipenguasaan BPJS Kesehatan, dan melaporkan perkembangannya kepada Kemenkes dan Kemensos dalam rangka koordinasi alamat peserta; (3) Kepala grup SDS dan Umum melakukan kegiatan promosi lewat media yang langsung menggunakan media yang ditujukan; (4) Berkoordinasi dengan Pemda terkait integrasi Jamkesda; (5) Penetapan IKU yang mampu mewujudkan kemandirian keuangan; dan (6) Berkoordinasi dengan Kementerian Sosial untuk data PBI yang tidak akurat.
\end{abstract}

Kata Kunci: Implementasi Kebijakan, Keuangan Negara, Jaminan Kesehatan Nasional.

\section{Abstract}

The purpose of this study was to analyze the implementation of the follow-up policy on the results of the examination of state finances in the implementation of the National Health Insurance. Research uses a qualitative research approach. Data collection was carried out using interview, observation and documentation study techniques. Data analysis was performed descriptively with the observers' triangulation analysis. The results of the study found that the implementation of the follow-up results of the examination was not yet fully effective, because 5 of the 26 recommendations that had been followed up by the Health BPJS were not in accordance with the recommendations of the Supreme Audit Agency. The implementation of the policy on the follow up of the results of the state financial audit in the implementation of the National Health Insurance covers actions and improvements that include: (1) Establishment of adequate regulations related to testing the truth of BU PPU data; (2) Distribution of KIS which is still in the possession of the Health BPJS, and report its progress to the Ministry of Health and Ministry of Social Affairs in the context of coordinating participant addresses; (3) The head of the SDS and General groups carries out promotional activities through the media directly using the intended media; (4) Coordinating with the Regional Government regarding the integration of Jamkesda; (5) Determination of 
KPI that is able to realize financial independence; and (6) Coordinate with the Ministry of Social Affairs for inaccurate PBI data.

Keywords: Policy Implementation, State Finance, National Health Insurance.

\section{A. PENDAHULUAN}

BPJS Kesehatan bertugas untuk: a). melakukan dan/atau menerima pendaftaran Peserta; b). memungut dan mengumpulkan Iuran dari Peserta dan Pemberi Kerja; c). menerima Bantuan Iuran dari Pemerintah; d). mengelola Dana Jaminan Sosial untuk kepentingan Peserta; e). mengumpulkan dan mengelola data Peserta program Jaminan Sosial; f). membayarkan Manfaat dan/atau membiayai pelayanan kesehatan sesuai dengan ketentuan program Jaminan Sosial; dan g). memberikan informasi mengenai penyelenggaraan program Jaminan Sosial kepada Peserta dan masyarakat.

BPJS Kesehatan berkewajiban untuk: a). memberikan nomor identitas tunggal kepada Peserta; b). mengembangkan aset Dana Jaminan Sosial dan aset BPJS untuk sebesarbesarnya kepentingan Peserta; c). memberikan informasi melalui media massa cetak dan elektronik mengenai kinerja, kondisi keuangan, serta kekayaan dan hasil pengembangannya; d). memberikan Manfaat kepada seluruh Peserta sesuai dengan Undang-Undang tentang Sistem Jaminan Sosial Nasional; e). memberikan informasi kepada Peserta mengenai hak dan kewajiban untuk mengikuti ketentuan yang berlaku; f). memberikan informasi kepada Peserta mengenai prosedur untuk mendapatkan hak dan memenuhi kewajibannya; g). memberikan informasi kepada Peserta mengenai saldo jaminan hari tua dan pengembangannya 1 (satu) kali dalam 1 (satu) tahun; h). memberikan informasi kepada Peserta mengenai besar hak pensiun 1 (satu) kali dalam 1 (satu) tahun; i). i. membentuk cadangan teknis sesuai dengan standar praktik aktuaria yang lazim dan berlaku umum; j). melakukan pembukuan sesuai dengan standar akuntansi yang berlaku dalam penyelenggaraan Jaminan Sosial; dan k). melaporkan pelaksanaan setiap program, termasuk kondisi keuangan, secara berkala 6 (enam) bulan sekali kepada Presiden dengan tembusan kepada DJSN. Agar Jaminan Sosial Nasional dapat terselenggara secara efektif dan akuntabel, BPJS Kesehatan berkewajiban melaksanakan tugasnya secara transparan, profesional, efektif, efisien dan akuntabel dalam memenuhi kebutuhan dan harapan Peserta JKN.

BPJS Kesehatan belum optimal dalam memenuhi kebutuhan dan harapan Peserta JKN, sebagai akibat BPJS Kesehatan belum optimal dalam memenuhi kewajibannya kepada penyelenggara Fasilitas Kesehatan yang menjaid mitra kerjanya. Sementara itu, akuntabilitas 
kinerja pengelolaan keuangan BPJS Kesehatan juga belum optimal. Hal ini terungkap dari Laporan Hasil Pemeriksaan Badan Pemeriksa Keuangan yang menyebutkan bahwa hasil pemeriksaan menunjukkan bahwa penyelenggaraan Program JKN pada BPJS Kesehatan belum sepenuhnya efektif. Berdasarkan hasil pemeriksaan masih terdapat beberapa permasalahan yang perlu mendapat perhatian antara lain bahwa data peserta penerima bantuan iuran yang dikelola oleh BPJS Kesehatan tidak akurat; BPJS Kesehatan dalam merekrut peserta baru dari golongan PPU BU tidak melakukan pengujian kebenaran data yang disampaikan oleh perusahaan; dan penetapan indikator kinerja utama belum mewujudkan kemandirian keuangan BPJS Kesehatan.

Berdasarkan beberapa permasalahan dari BPJS Kesehatan di atas, maka tujuan penelitian ini adalah untuk menganalisis implementasi kebijakan tindak lanjut hasil pemeriksaan keuangan negara dalam penyelenggaraan Jaminan Kesehatan Nasional.

\section{B. TINJAUAN PUSTAKA}

Kerangka teori disusun dengan mendeskripsikan grand theory Ilmu Pemerintahan; middle range theory Teori Administrasi Pemerintahan; dan applied theory Teori Implementasi Kebijakan Publik dan Teori Pemeriksaan Keuangan Negara. Dari eksplorasi applied theory dipilih model implementasi kebijakan publik Van Meter \& Van Horn sebagai landasan teoritik penyusunan konsep dan instrumen penelitian.

Hill \& Hupe, 2002:45) mengatakan: Van Meter and Van Horn go on to suggest a model in which six variables are linked dynamically to the production of an outcome 'performance'. The six variables are: 1). Policy standard and objective; 2). The resources and incentives; 3).The quality of inter-organizational relationships; 4). The characteristics of the implementation agencies; 5). The economic, social and political environment; and 6). The disposition or response of the implementers.

Van Meter \& Van Horn (1975:462), merancang model implementasi kebijakan dengan mengatakan bahwa ada enam variabel yang membentuk hubungan antara kebijakan dan kinerja, dengan penjelasan berikut: This model not only specifies the relationships between the independent variables and the ultimate dependent variable of interest, but also makes explicit the relationships among the independent variables. The linkages included implicitly represent hypotheses which could be tested empirically, assuming that satisfactory indicators could 'be constructed and appropriate data collected. By approaching the problem in this manner, there is greater promise for elucidating the processes whereby policy JURNAL PAPATUNG: Vol. 3 No. 1 Tahun 2020 
decisions are carried out than simply by correlating .independent and dependent variables in a relatively unthinking fashion (Van Meter \& Asher, 1973). The model has been constructed on the basis of the three bodies of literature cited above, as well as the authors' own research and intuitions about the implementation process.

Dengan model implementasi kebijakan publik Van Meter \& Van Horn disusun definisi konsep bahwa Implementasi Kebijakan Tindak Lanjut Hasil Pemeriksaan Keuangan Negara dalam penyelenggaraan Jaminan Kesehatan Nasional adalah pelaksanaan Peraturan Badan Pemeriksa Keuangan Nomor 2 Tahun 2017 Tentang Pemantauan Pelaksanaan Tindak Lanjut Rekomendasi Hasil Pemeriksaan Badan Pemeriksa Keuangan yang dianalisis menurut policy standard and objective; the resources and incentives; the quality of interorganizational relationships; the characteristics of the implementation agencies; the economic, social and political environment; the disposition or response of the implementers. Definisi diturunkan menjadi 6 dimensi sebagai berikut: (1) Dimensi policy standard and objective; (2) Dimensi the resources and incentives; (3) Dimensi the quality of interorganizational relationships; (4) Dimensi the characteristics of the implementation agencies; (5) Dimensi the economic, social and political environment; (6) Dimensi the disposition of the implementers. Enam dimensi dikembangkan menjadi 18 Pokok Pertanyaan yang tersusun dalam Pedoman Wawancara.

\section{METODE PENELITIAN}

Penelitian ini menggunakan pendekatan kualitatif. Penentuan Informan Penelitian sebanyak 4 orang menggunakan snow ball technique. Pengumpulan data dilakukan dengan menggunakan teknik wawancara, observasi dan studi dokumentasi. Analisis data dilakukan secara deskriptif dengan analisis triangulasi para pengamat. Teknik analisis data dilakukan secara deskriptif dengan metode triangulasi pengamat dan disusun menurut enam dimensi model implementasi kebijakan publik Van Meter \& Van Horn hingga dicapai Implikasi Praktis dari dari masing-masing dimensi analisis.

\section{HASIL DAN PEMBAHASAN}

1. Implementasi Kebijakan Tindak Lanjut Hasil Pemeriksaan Pemeriksaan Keuangan Negara Dalam Penyelenggaraan Jaminan Kesehatan Nasional

Analisis Policy Standard and Objective: Von Meter \& Von Horn (1975:464) menjelaskan: "Given our primary interest in the factors that determine the performance of JURNAL PAPATUNG: Vol. 3 No. 1 Tahun 2020 
policy, the identification of performance indicators is a crucial stage in the analysis. Essentially, the performance indicators assess the extent to which the policy's standards and objectives are realized. Standards and objectives elaborate on the overall goals. of the policy decision. They move beyond the generalities of the legislative document to provide concrete and more specific standards for assessing program performance. These standards and objectives are self-evident and easily measurable in some cases. To ascertain whether implementation has been successful, one must determine the number of jobs that have been created, the identity of those who have been hired, and the progress on the related public works projects." Dengan rujukan pendapat ini, dari analisis Policy Standard and Objective disusun implikasi praktis implementasi kebijakan tindak lanjut hasil pemeriksaan pengelolaan keuangan Negara pada BPJS Kesehatan sebagai berikut :

Standar kebijakan dan tujuan implementasi Kebijakan Tindak Lanjut Hasil Pemeriksaan meliputi tindakan-tindakan tertentu dan perbaikan-perbaikan tertentu yang direkomendasikan oleh pejabat pemeriksa kepada entitas terperiksa berdasarkan hasil pemeriksaan atas kinerja pengelolaan dan tanggungjawab keuangan negara. Hasil pemeriksaan yang dicapai melalui proses identifikasi, analisis, dan evaluasi dilakukan secara independen, obyektif, dan profesional menurut standar pemeriksaan guna menilai kebenaran, kecermatan, kredibilitas, dan keandalan informasi tata kelola dan tanggung jawab keuangan negara. Implementasi bertujuan mendukung terwujudnya kinerja penyelenggaraan JKN yang mampu memberikan pelayanan prima kepada setiap peserta Program JKN. Untuk itu, diperlukan berbagai upaya yang lebih terintegrasi untuk meningkatkan efektivitas implementsi kebijakan tindak lanjut hasil pemeriksaan pengelolaan keuangan negara dalam penyelenggaraan Jaminan Nasional Kesehatan. Berbagai upaya yang dimaksud antara lain dilakukan dengan mendeskripsikan standar kebijakan dan tujuan implementasi kebijakan tindak lanjut hasil pemeriksaan yang lebih kritis, cermat dan progresif dengan menunjukkan konsekuensi dan sanksi terhadap setiap tindakan tertentu dan perbaikan-perbaikan tertentu yang direkomendasikan oleh pejabat pemeriksa kepada entitas terperiksa.

Analisis Policy Resources and Incentives: Van Meter \& Van Horn (975:465) menjelaskan: "Policies furnish more than the standards and objectives against which to judge implementation: they also make available resources which facilitate their administration. These resources may include funds or other incentives in the program that might encourage or facilitate effective implementation". 
Dengan rujukan pendapat ini, dari analisis Policy Resources and Incentives disusun Implikasi Praktis implementasi kebijakan tindak lanjut hasil pemeriksaan pengelolaan keuangan Negara pada BPJS Kesehatan sebagai berikut: Sumber daya dan insentif dalam proses implementasi kebijakan tindak lanjut hasil pemeriksaan tidak terbatas hanya pada sumber daya manusia, sumber daya anggaran, dan infrastruktur. Terdapat sumber daya dan insentif lain yang lebih bisa mendesak dilakukannya tindakan-tindakan tertentu dan perbaikan-perbaikan tertentu yang direkomendasikan oleh pejabat pemeriksa kepada entitas terperiksa. Sumber daya lain yang dimaksud adalah sumber daya regulasi yang bisa digunakan untuk mendesak dilakukannya perbaikan-perbaikan tertentu dan sumber daya instansi terkait yang bisa dilibatkan untuk mendesak dilakukannya tindakan-tindakan tertentu. Sedangkan insentif lain yang dimaksud adalah aplikasi teknologi informasi untuk mengelola data peserta penerima bantuan iuran agar menjadi akurat; dan mempermudah pelayanan perubahan data kepesertaan BPJS Kesehatan. Karena itu, diperlukan optimalisasi penggunaan sumber daya regulasi untuk mendesak dilakukannya perbaikan-perbaikan tertentu agar kualitas pelayanan BPJS Kesehatan semakin modern, profesional dan akuntabel dalam melayani kebutuhan para peserta JKN dan menjalin kerjasama dengan penyelenggara fasilitas kesehatan. Untuk itu, diperlukan juga optimalisasi pelibatan sumber daya instansi terkait untuk mendesak dilakukannya tindakan-tindakan tertentu yang terkait dengan pertanggujawaban atas Dana JKN yang belum sepenuhnya digunakan sesuai dengan peruntukan; dan penempatan dana JKN yang belum memberikan keuntungan optimal.

Analisis Inter organizational Communication and Enforcement Activities: Van Meter dan Van Horn (1975:466) mengatakan: Effective implementation requires that a program's standards and objectives be understood by those individuals responsible for their achievement. Hence, it is vital that concern our selves with the clarity of standards and objectives, the accuracy of .their communication to implementers, and the consistency (or uniformity): with which they are communicated by various sources of information. Standards and objectives cannot be carried out unless they are stated with sufficient clarity so that implementers can know what is expected of them. Communication within and between organizations is a complex and difficult process. In transmitting messages downward in an organization, or from one organization to another, communicators inevitably distort themboth intentionally and unintentionally (Downs, 1967:133-136). Furthermore, if different sources of communication provide inconsistent interpretations of standards and objectives or if the same source provides conflicting interpretations over time, implementers will find it 
even more difficult to carry out the intentions of policy. Therefore, the prospects of effective implementation will be enhanced by the clarity with which standards and objectives are stated and by the accuracy and consistency with which they are communicated.

Dengan rujukan pendapat ini, dari analisis Inter organizational Communication and Enforcement Activities disusun Implikasi Praktis dari analisis implementasi kebijakan tindak lanjut hasil pemeriksaan pengelolaan keuangan Negara pada BPJS Kesehatan sebagai berikut: Aktivitas komunikasi antar organisasi yang berlangsung dalam proses implementasi kebijakan tindak lanjut hasil pemeriksaan meliputi aktivitas komunikasi, aktivitas koordinasi dan aktivitas komfirmasi. Aktivitas komunikasi terdiri dari komunikasi antar personal, komunikasi antar unit kerja dan komunikasi antar organisasi. Pelaksanaan fungsi komunikasi terkait dengan kebutuhan koordinasi personal, koordinasi structural dan koordinasi fungsional serta kebutuhan komfirmasi data fungsional, komfirmasi data factual dan komfirmasi data kondisional. Aktivitas koordinasi yang terdiri dari koordinasi personal, koordinasi structural dan koordinasi fungsional terkait dengan peran dan tanggungjawab pejabat, fungsi jabatan dan kinerja jabatan. Aktivitas komfirmasi yang terdiri dari komfirmasi data fungsional, komfirmasi data factual dan komfirmasi data kondisional terkait dengan kebutuhan untuk menilai tindak-tindakan tertentu dan perbaikan-perbaikan tertentu yang direkomendasikan oleh pejabat pemeriksa kepada entitas terperiksa. Dari aktivitas komunikasi antar organisasi inilah kemudian diketahui proses implementasi yang bisa terdiri atas (1) tindak lanjut telah sesuai dengan rekomendasi; (2) tindak lanjut belum sesuai dengan rekomendasi; (3) rekomendasi belum ditindaklanjuti; dan atau (4) rekomendasi tidak dapat ditindaklanjuti. Karena itu, untuk mengoptimalkan implementasi kebijakan tindak lanjut hasil pemeriksaan pengelolaan dan tanggungjawab keuangan Negara diperlukan penerapan strategi komunikasi yang lebih intensif untuk mengoptimalkan tindakan-tindakan tertentu dan perbaikanperbaikan tertentu yang direkomendasikan oleh pejabat pemeriksa kepada entitas terperiksa.

Analisis the Characteristic of the Implementing Agencies: Van Meter dan Van Horn (1975:470) menjelaskan: "Numerous factors are included in this component of the model. Students of bureaucratic politics have identified many characteristics of administrative agencies that affect their policy performance. Ripley et al. (1973: to), for example speak of bureaucratic structure as those "characteristics, norms, and recurring patterns of relations inside the executive agencies that have either potential or actual relation to what they do in the way of policy." Like Ripley, we view this component as consisting of both the formal structural features of organizations and the informal attributes of their personnel. Without JURNAL PAPATUNG: Vol. 3 No. 1 Tahun 2020 
trying to provide an exhaustive listing of these elements we offer the following suggestions of characteristics that may impinge on an organization's capacity to implement policy: 1). The competence and size of an agency's staff; 2). The degree of hierarchical control of subunit decisions and processes within the implementing agencies; 3). an agency's political resources (e.g., support among legislators and executives); 4). The vitality of an organization; 5). The degree of "open" communications (ie., networks of communication with free horizontal and vertical communication, and a relatively high degree of freedom in communications with persons outside the organization) within an organization; and 6). The agency's formal and informal linkages with the "policy making" or "policy - enforcing" body.

Dengan rujukan pendapat ini, dari analisis the Characteristic of the Implementing Agencies disusun Implikasi Praktis dari analisis implementasi kebijakan tindak lanjut hasil pemeriksaan pengelolaan keuangan Negara pada BPJS Kesehatan sebagai berikut: Karakteristik lembaga pelaksana kebijakan tindak lanjut hasil pemeriksaan teridentifikasi dari kedudukan Dewan Pengawas dan Direksi. Dewan Pengawas merupakan organ BPJS Kesehatan yang bertugas untuk melakukan pengawasan atas pelaksanaan pengurusan BPJS Kesehatan oleh Direksi dan memberikan nasihat kepada Direksi dalam penyelenggaraan program Jaminan Sosial Kesehatan oleh BPJS Kesehatan. Direksi BPJS Kesehatan berwenang dan bertanggung jawab penuh atas pengurusan BPJS Kesehatan untuk kepentingan BPJS Kesehatan, sesuai dengan asas, tujuan, dan prinsip BPJS Kesehatan, serta mewakili BPJS Kesehatan, baik di dalam maupun di luar pengadilan. Direksi BPJS Kesehatan berfungsi melaksanakan kegiatan operasional yang menjamin Peserta untuk mendapatkan manfaat sesuai dengan haknya. Jabatan Direksi dilaksanakan secara kolektif kolegial (board), dimana kedudukan masing-masing anggota Direksi termasuk Direktur Utama adalah setara. Dengan demikian tidak terdapat jabatan top leader yang paling berwenang menentukan keputusan atas tindakan-tindakan dan perbaikan-perbaikan tertentu yang direkomendasikan oleh pejabat pemeriksa kepada entitas terperiksa.

Dengan pelaksanaan fungsi pengawasan internal yang belum efektif maka pelaksanaan tindakan-tindakan dan perbaikan-perbaikan yang direkomendasikan cenderung tidak sepenuhnya efektif. Karena itu, untuk mengefektikan implementasi kebijakan tindak lanjut hasil pemeriksaan pengelolaan dan tanggungjawab keuangan Negara dalam penyelenggaraan Jaminan Kesehatan Nasional diperlukan penerapan strategi pendekatan yang lebih intensif agar tindakan-tindakan dan perbaikan-perbaikan yang direkomendasikan oleh pejabat pemeriksa kepada entitas terperiksa dapat terlaksana secara efektif. 
Analisis Economic, Social and Political Environment: Van Meter dan Van Horn (1975:472) menjelaskan: "The impact of economic, social, and political conditions on public policy has been the focus of much attention during the past decade. Students of comparative state politics and public policy have been particularly interested in identifying the influence of these environmental variables on policy outputs (see, for example, Sharkansky, 1967, 1971; Sharkansky and Hofferbert, 1969; Cnudde and McCrone, 1969; Dye, 1966; Hofferbert, 1964). Although the impact of these factors on the implementation of policy decisions has received little attention, they may have a profound effect on the performance of implementing agencies.

Dengan rujukan pendapat ini, dari analisis Economic, Social and Political Environment disusun Implikasi Praktis dari analisis implementasi kebijakan tindak lanjut hasil pemeriksaan pengelolaan keuangan Negara pada BPJS Kesehatan sebagai berikut: Lingkungan politik, sosial dan ekonomi, secara langsung atau tidak langsung dapat mempengaruhi implementasi kebijakan tindak lanjut hasil pemeriksaan pengelolaan keuangan Negara dalam penyelenggaraan Jaminan Kesehatan Nasional. Lingkungan ekonomi mempengaruhi tindakan-tindakan dan perbaikan-perbaikan yang direkomendasikan oleh pejabat pemeriksa kepada entitas terperiksa melalui iuran kepesertaan JKN. Lingkungan social mempengaruhi tindakan-tindakan dan perbaikan-perbaikan yang direkomendasikan oleh pejabat pemeriksa kepada entitas terperiksa melalui partisipasi kepesertaan JKN. Lingkungan politik mempengaruhi tindakan-tindakan dan perbaikan-perbaikan yang direkomendasikan oleh pejabat pemeriksa kepada entitas terperiksa melalui mekanisme pertanggungjawaban BPJS Kesehatan kepada Presiden dan DPR. Ketidakmampuan BPJS Kesehatan dalam menyikapi dinamika kebutuhan dan tuntutan lingkungan ekonomi, social dan politik yang terkait dengan kepersertaan JKN terindikasi dari tindak lanjut hasil pemeriksaan. Tindak lanjut hasil pemeriksaan yang terdiri dari tindakan-tindakan dan perbaikan-perbaikan tertentu yang direkomendasikan yang tidak hanya bertujuan meningkatkan kinerja pelayanan public BPJS namun bertujuan meningkatkan juga kapasitas kelembagaan BPJS Kesehatan dalam menjalin kerjasama kemitraan dengan penyelenggara fasilitas kesehatan, terutama dalam memenuhi kewajiban BPJS Kesehatan kepada penyelenggara fasilitas kesehatan. Karena itu, untuk meningkatkan kemampuan BPJS Kesehatan dalam melaksanakan tindakan-tindakan dan perbaikan-perbaikan tertentu yang direkomendasikan oleh pejabat pemeriksa diperlukan dukungan Presiden dan DPR agar 
tindakan-tindakan dan perbaikan-perbaikan yang direkomendasikan dapat terlaksana secara efektif.

Analisis the Disposition of Implementers: Van Meter dan Van Horn (1975:474) mengatakan: "Finally, the intensity of implementers' dispositions may affect the performance of the policy. Less intense attitudes may cause implementers to attempt surreptitious diversion and evasion, a more common pattern. In these circumstances one may have to look to the role of oversight and enforcement to explain variations in the effectiveness of implementation. Dengan rujukan pendapat ini, dari analisis the Disposition of Implementers disusun Implikasi Praktis dari analisis implementasi kebijakan tindak lanjut hasil pemeriksaan pengelolaan keuangan Negara pada BPJS Kesehatan sebagai berikut: Disposisi pelaksana kebijakan, dapat mempengaruhi implementasi kebijakan tindak lanjut hasil pemeriksaan pengelolaan keuangan Negara dalam penyelenggaraan Jaminan Kesehatan Nasional. Disposisi yang dimaksud merupakan suatu penyimpangan yang harus diantisipasi. Antisipasi yang dimaksud dapat meliputi: Pertama, terhadap disposisi yang dapat menurunkan kualitas pelayanan publik yang diselenggarakan oleh BPJS Kesehatan; kedua, terhadap disposisi yang dapat menimbulkan kerugian negara; dan ketiga, terhadap disposisi yang dapat menghambat proses pencapaian tujuan penyelenggaraan program Jaminan Kesehatan Nasional. Fenomena disposisi yang dapat menurunkan kualitas pelayanan publik yang diselenggarakan oleh BPJS Kesehatan tidak hanya berdampak pada peserta Jaminan Kesehatan Nasional; namun berdampak pula pada pembangunan sumber daya manusia. Disposisi yang dapat menimbulkan kerugian negara tidak hanya berdampak pada perekonomian negara; namun berdampak pula pada perekonomian masyarakat. Sedangkan disposisi yang dapat menghambat proses pencapaian tujuan penyelenggaraan program JKN menjadi kendala pencapaian tujuan penyelenggaraan pemerintahan negara sebagaimana yang tertulis menjadi Pembukaan Undang-Undang dasar 1945. Karena itu, diperlukan berbagai upaya untuk menyikapi, mengatasi dan sekaligus mengantisipasi kemungkinan terjadinya disposisi, agar tindakan-tindakan dan perbaikan-perbaikan yang direkomendasikan dapat terlaksana secara efektif. 


\section{Konsep Baru Hasil Pembahasan Implementasi Kebijakan Tindak Lanjut Hasil} Pemeriksaan Keuangan Negara Dalam Penyelenggaraan Jaminan Kesehatan Nasional

Konsep Baru yang dapat disusun dari Hasil Pembahasan Implementasi Kebijakan Tindak Lanjut Hasil Pemeriksaan Keuangan Negara Dalam Penyelenggaraan Jaminan Kesehatan Nasional adalah berikut:

Landasan Teoritik: Van Meter and Van Horn, sebagaimana diungkapkan oleh Hill and Hupe (2002:45) yang mengatakan: Van Meter and Van Horn go on to suggest a model in which six variables are linked dynamically to the production of an outcome 'performance'. The six variables (surely are in fact clusters of variables) are: 1). Policy standard and objective, which elaborate on the overall goals of the policy decision to provide concrete and more specific standards for assessing performance; 2). The resources and incentives made available; 3).The quality of inter-organizational relationships (we find in their discussions of this, as in so much of the American literature on implementation, an extensive discussion of aspects of federalism); 4). The characteristics of the implementation agencies, including issues like organizational control but also, going back surely to inter-organizational issues, the agency's formal and informal linkages with the "policy-making" or "policy-enforcing" body; 5). The economic, social and political environment; and 6). The disposition or response of the implementers, involving three elements: their cognition (comprehension, understanding) of the policy, the direction of their response to it (acceptance, neutrality, rejection) and the intensity of that response.

Berdasarkan teori implementasi kebijakan publik Von Meter and Von Horn disusun Definisi Konsep bahwa Implementasi Kebijakan Tindak Lanjut Hasil Pemeriksaan Keuangan Negara dalam penyelenggaraan Jaminan Kesehatan Nasional adalah pelaksanaan Peraturan Badan Pemeriksa Keuangan Nomor 2 Tahun 2017 Tentang Pemantauan Pelaksanaan Tindak Lanjut Rekomendasi Hasil Pemeriksaan Badan Pemeriksa Keuangan yang dianalisis menurut policy standard and objective; the resources and incentives; the quality of interorganizational relationships; the charac-teristics of the implementation agencies; the economic, social and political environment; the disposition or response of the implementers. Dari definisi konsep dikembangkan enam dimensi analisis berikut: (1) Dimensi policy standard and objective; (2) Dimensi the resources and incentives; (3) Dimensi the quality of inter-organizational relationships; (4) Dimensi the characteristics of the implementation agencies; (5) Dimensi the economic, social and political environment; dan (6) Dimensi the 
disposition or response of the implementers. Enam dimensi dikembangkan dan diajukan menjadi 18 Pokok Pertanyaan Terbuka yang tersusun dalam Pedoman Wawancara.

Landasan Empirik: Dari analisis deskriptif terhadap enam variabel atau enam factor yang terungkap dari fenomena Implementasi Kebijakan Tindak Lanjut Hasil Pemeriksaan dalam penyelenggaraan Jaminan Kesehatan Nasional yang menjadi penentu efektivitas proses implementasi kebijakan tersebut. Enam faktor yang dimaksud adalah (1) Standar kebijakan dan tujuan implementasi kebijakan; (2) Sumber daya dan insentif implementasi kebijakan; (3) Aktivitas komunikasi antar organisasi; (4) Karakteristik lembaga pelaksana kebijakan; (5) Lingkungan politik, social dan ekonomi; dan (6) Disposisi dan sikap pelaksana kebijakan. Di antara enam factor tersebut, aktivitas komunikasi antar organisasi menjadi faktor yang paling dominan pengaruhnya terhadap efektivitas implementasi kebijakan tindak lanjut hasil pemeriksaan. Aktivitas komunikasi antar organisasi yang dimaksud meliputi Aktivitas Komunikasi; Aktivitas Koordinasi; dan Aktivitas Komfirmasi dalam proses pemantauan dan penilaian terhadap tindakan-tindakan dan perbaikan-perbaikan tertentu yang direkomendasikan oleh pejabat pemeriksa kepada entitas terperiksa.

Aktivitas komunikasi antar organisasi yang berlangsung dalam proses implementasi kebijakan tindak lanjut hasil pemeriksaan meliputi aktivitas komunikasi, aktivitas koordinasi dan aktivitas komfirmasi. Aktivitas komunikasi terdiri dari komunikasi antar personal, komunikasi antar unit kerja dan komunikasi antar organisasi. Pelaksanaan fungsi komunikasi terkait dengan kebutuhan koordinasi personal, koordinasi structural dan koordinasi fungsional serta kebutuhan komfirmasi data fungsional, komfirmasi data factual dan komfirmasi data kondisional. Aktivitas koordinasi yang terdiri dari koordinasi personal, koordinasi structural dan koordinasi fungsional terkait dengan peran dan tanggungjawab pejabat, fungsi jabatan dan kinerja jabatan. Aktivitas komfirmasi yang terdiri dari komfirmasi data fungsional, komfirmasi data faktual dan komfirmasi data kondisional terkait dengan kebutuhan untuk menilai tindak-tindakan tertentu dan perbaikan-perbaikan tertentu yang direkomendasikan oleh pejabat pemeriksa kepada entitas terperiksa. Dari aktivitas komunikasi antar organisasi inilah kemudian diketahui proses implementasi yang bisa terdiri atas (1) tindak lanjut telah sesuai dengan rekomendasi; (2) tindak lanjut belum sesuai dengan rekomendasi; (3) rekomendasi belum ditindaklanjuti; dan atau (4) rekomendasi tidak dapat ditindaklanjuti. Karena itu, untuk mengoptimalkan implementasi kebijakan tindak lanjut hasil pemeriksaan pengelolaan dan tanggungjawab keuangan Negara diperlukan penerapan strategi komunikasi yang lebih intensif untuk mengoptimalkan tindakan-tindakan tertentu dan 
perbaikan-perbaikan tertentu yang direkomendasikan oleh pejabat pemeriksa kepada entitas terperiksa.

Dominannya pengaruh aktivitas komunikasi antar organisasi terhadap efektivitas Implementasi Kebijakan Tindak Lanjut Hasil Pemeriksaan karena aktivitas komunikasi antar organisasi tersebut membentuk nilai-nilai, kapasitas dan intensitas kinerja pemantauan dan penilaian terhadap seluruh tindak lanjut hasil pemeriksaan. Dengan demikian fakta empirik menunjukkan bahwa aktivitas komunikasi antar organisasi dalam proses implementasi kebijakan menjadi faktor yang paling dominan pengaruhnya terhadap keberhasilan setiap tindakan dan atau perbaikan yang direkomendasikan oleh Badan Pemeriksa Keuangan (BPK) kepada Badan Penyelenggara Jaminan Sosial Kesehatan (BPJS Kesehatan). Fakta emprik yang demikian selanjutnya dijadikan temuan penelitian (research finding) yang menjadi dasar penyusunan Konsep Baru.

Konsep Baru: Konsep baru yang didapat dari analisis implementasi kebijakan tindak lanjut hasil pemeriksaan keuangan Negara dalam penyelenggaraan Jaminan Kesehatan Nasional adalah konsep baru tentang Komunikasi Tindak Lanjut Hasil Pemeriksaan Pengelolaan Keuangan Negara. Definisi, deskripsi dan proposisi yang terkonstruksi pada konsep baru tersebut adalah berikut:

Definisi Komunikasi Tindak Lanjut Hasil Pemeriksaan Pengelolaan Keuangan Negara: Komunikasi Tindak Lanjut Hasil Pemeriksaan Pengelolaan Keuangan Negara adalah rangkaian aktivitas komunikasi antar organisasi yang berlangsung dalam proses implementasi kebijakan tindak lanjut hasil pemeriksaan yang meliputi aktivitas komunikasi, aktivitas koordinasi dan aktivitas komfirmasi yang diperlukan untuk mendesak dilakukannya tindakan-tindakan tertentu dan perbaikan-perbaikan tertentu yang direkomendasikan oleh pejabat pemeriksa kepada entitas terperiksa. Definisi mencakup empat dimensi analisis: (1) Dimensi Aktivitas Komunikasi; (2) Dimensi Aktivitas Koordinasi; dan (3) Dimensi Aktivitas Komfirmasi.

Deskripsi Komunikasi Tindak Lanjut Hasil Pemeriksaan Pengelolaan Keuangan Negara: Deskripsi tiga dimensi analisis Komunikasi Tindak Lanjut Hasil Pemeriksaan Pengelolaan Keuangan Negara adalah berikut: Aktivitas Komunikasi adalah kinerja pengelolaan infomasi dan data mengenai tindakan-tindakan dan perbaikan-perbaikan tertentu yang direkomendasikan oleh pejabat pemeriksa kepada entitas terperiksa yang berlangsung sebagai suatu rangkaian kegiatan pemantauan guna memberi penilaian terhadap tindakantindakan dan perbaikan-perbaikan tertentu yang direkomendasikan. Aktivitas komunikasi 
terdiri dari komunikasi antar personal, komunikasi antar unit kerja dan komunikasi antar organisasi. Pelaksanaan fungsi komunikasi terkait dengan kebutuhan koordinasi personal, koordinasi structural dan koordinasi fungsional serta kebutuhan komfirmasi data fungsional, komfirmasi data factual dan komfirmasi data kondisional. Pendekatan komunikasi dilakukan untuk memperjelas dan memastikan kebenaran dan kabsahan informasi atau data. Dalam konteks ini, pemilihan media, metode, pesan dan waktu berkomunikasi yang cermat dan tepat menjadi penting sekali. Dan karena informasi atau data yang didapat dari aktivitas komunikasi dijadikan dasar pengambilan suatu keputusan, maka pemanfaatan informasi atau data tersebut harus benar-benar teruji kebenaran atau keabsahannya. Untuk itu, komfirmasi data adalah salah satu cara memastikan validitas data yang diperoleh dari berbagai kegiatan pemeriksaan, dan juga untuk merumuskan hal-hal yang perlu direkomendasikan. Aktivitas komunikasi harus dapat memperjelas "apa, mengapa, dimana, siapa, kapan, dan bagaimana" tindakan-tindakan atau perbaikan-perbaikan tertentu itu dilaksanakan, agar dengan demikian efektivitas dan atau hasil tindakan-tindakan atau perbaikan-perbaikan yang direkomendasikan dapat diketahui. Kendala dalam pelaksanaan fungsi komuniasi adalah sikap pejabat yang tertutup, tidak kooperatif dan keterbatasan informasi dan yang diperlukan.

Aktivitas koordinasi adalah kinerja pengintegrasian dan penyelarasan sumber daya dan cara-cara yang digunakan untuk melaksanakan tindakan-tindakan dan perbaikanperbaikan tertentu yang direkomendasikan oleh pejabat pemeriksa kepada entitas terperiksa yang berlangsung sebagai suatu rangkaian kegiatan pemantauan guna memberi penilaian terhadap tindakan-tindakan dan perbaikan-perbaikan tertentu yang direkomendasikan. Aktivitas koordinasi dapat terdiri dari koordinasi personal, koordinasi struktural, koordinasi fungsional dan koordinasi teknis operasional. Pendekatan koordinasi dilakukan untuk memperjelas, mempermudah dan memperlancar proses implementasi kebijakan tindak lanjut hasil pemeriksaan. Karena hasil koordinasi merupakan salah satu acuan pengambilan suatu keputusan, maka pemanfaatan hasil koordinasi harus benar-benar dapat memperjelas, mempermudah dan atau memperlancar teknis pelaksanaan tindakan-tindakan dan atau perbaikan-perbaikan tertentu yang direkomendasikan pejabat pmeriksa kepada entitas terperiksa. Pendekatan koordinasi hendaknya dilakukan dengan perencanaan koordinasi yang cermat. Kendala dalam pelaksanaan fungsi koordinasi adalah arogansi jabatan dan ego sektoral.

Aktivitas Komfirmasi adalah kinerja pemeriksaan informasi dan data yang terkait dengan pelaksanaan tindakan-tindakan dan perbaikan-perbaikan tertentu yang 
direkomendasikan oleh pejabat pemeriksa kepada entitas terperiksa yang berlangsung sebagai suatu rangkaian kegiatan pemantauan guna memberi penilaian terhadap tindakantindakan dan perbaikan-perbaikan tertentu yang direkomendasikan. Aktivitas komfirmasi meliputi komfirmasi data fungsional, komfirmasi data factual dan komfirmasi data kondisional yang terkait dengan kebutuhan untuk menilai tindak-tindakan tertentu dan perbaikan-perbaikan tertentu yang direkomendasikan oleh pejabat pemeriksa kepada entitas terperiksa. Aktivitas komfirmasi dilakukan untuk memeriksa dan menilai kebenaran, kecermatan, keabsahan, kelengkapan, kejelasan dan tanggungjawab sumber data seputar tindak-tindakan tertentu dan perbaikan-perbaikan tertentu yang direkomendasikan oleh pejabat pemeriksa kepada entitas terperiksa. Kendala dalam melaksanakan fungsi komfirmasi adalah manipulasi data.

\section{E. KESIMPULAN}

Implementasi Kebijakan Tindak Lanjut Hasil Pemeriksaan Keuangan Negara Dalam Penyelenggaraan Jaminan Kesehatan Nasional meliputi tindakan-tindakan dan perbaikanperbaikan yang meliputi (1) Penetapan regulasi yang memadai terkait pengujian kebenaran data PPU BU; (2) Pendistribusian KIS yang masih berada dipenguasaan BPJS Kesehatan, dan melaporkan perkembangannya kepada Kemenkes dan Kemensos dalam rangka koordinasi alamat peserta; (3) Kepala grup SDS dan Umum melakukan kegiatan promosi lewat media yang langsung menggunakan media yang ditujukan; (4) Berkoordinasi dengan Pemda terkait integrasi Jamkesda; (5) Penetapan IKU yang mampu mewujudkan kemandirian keuangan; dan (6) Berkoordinasi dengan Kementerian Sosial untuk data PBI yang tidak akurat. Pelaksanaan tindak lanjut hasil pemeriksaan tersebut belum sepenuhnya efektif, karena 5 dari 26 rekomendasi yang sudah ditindaklanjuti oleh BPJS Kesehatan belum sesuai dengan rekomendasi Badan Pemeriksa Keuangan.

Konsep baru yang didapat dari analisis implementasi kebijakan tindak lanjut hasil pemeriksaan keuangan Negara dalam penyelenggaraan Jaminan Kesehatan Nasional adalah konsep baru tentang Komunikasi Tindak Lanjut Hasil Pemeriksaan Pengelolaan Keuangan Negara yaitu rangkaian aktivitas komunikasi antar organisasi yang berlangsung dalam proses implementasi kebijakan tindak lanjut hasil pemeriksaan yang meliputi aktivitas komunikasi, aktivitas koordinasi dan aktivitas komfirmasi yang diperlukan untuk mendesak dilakukannya tindakan-tindakan dan perbaikan-perbaikan yang direkomendasikan oleh pejabat pemeriksa 
kepada entitas terperiksa. Definisi mencakup empat dimensi analisis: (1) Dimensi Aktivitas

Komunikasi; (2) Dimensi Aktivitas Koordinasi; dan (3) Dimensi Aktivitas Komfirmasi.

\section{DAFTAR PURSTAKA}

Agussalim, A., Hermiyanti, H., \& Rahman, A. (2017). Analisis Implementasi Kebijakan Jaminan Kesehatan Nasional (JKN) di Rumah Sakit Umum Daerah (RSUD) Undata Palu. Healthy Tadulako Journal (Jurnal Kesehatan Tadulako), 3(1), 62-70.

Damayanti, K. (2008). Evaluasi Implementasi Kebijakan Asuransi Kesehatan Masyarakat Miskin (Askeskin) dan Prospek Implementasi Jaminan Kesehatan Masyarakat (Jamkesmas). Jurnal Borneo Administrator, 4(2).

Hasanah, U. (2016). Implementasi Program Jaminan Kesehatan Nasional Pemberian Bantuaniuran di Puskesmas Kokop Kecamatan Kokop Kabupaten Bangkalan. Publika, 4(1).

Hill, M., \& Hupe, P. (2002). Implementing public policy: Governance in theory and in practice. London: SAGE Publications Ltd.

Karim, M. I. T., Moenta, A. P., \& Riza, M. (2018). Implementasi Kebijakan Pemerintah Daerah di Bidang Kesehatan Masyarakat Melalui Jaminan Kesehatan Nasional. Amanna Gappa, 26(1), 53-63.

Khariza, H. A. (2015). Program jaminan kesehatan nasional: studi deskriptif tentang faktorfaktor yang dapat mempengaruhi keberhasilan implementasi program jaminan kesehatan nasional di rumah sakit jiwa Menur Surabaya. Jurnal Kebijakan dan Manajemen Publik, 3(1), 1-7.

Malik, A. A. (2019). Implementasi Kebijakan Diskresi pada Pelayanan Kesehatan Badan Penyelenggara Jaminan Kesehatan (BPJS). Jurnal Ilmiah Kesehatan Sandi Husada, 18.

Muthalib, A. (2017). Implementasi Kebijakan Jaminan Kesehatan Nasional/JKN Bukan Penerima Bantuan Iuran Mandiri di Kabupaten Nunukan (Studi Kasus Peserta JKN Bukan Penerima Bantuan Iuran Mandiri di Kabupaten Nunukan)(Doctoral dissertation, Universitas Terbuka).

Nugraheni, S. W. (2015). Evaluasi Penerapan Jaminan Kesehatan Nasional (JKN) Di RSUD DR Moewardi Surakarta. Jurnal INFOKES Universitas Duta Bangsa Surakarta, 5(2).

Primasari, K. L. (2015). Analisis Sistem Rujukan Jaminan Kesehatan Nasional RSUD. Dr. Adjidarmo Kabupaten Lebak. Jurnal Administrasi Rumah Sakit Indonesia, 1(2).

Putra, W. M. (2015). Analisis Implementasi Kebijakan Jaminan Kesehatan Nasional di Rumah Sakit Umum Kota Tangerang Selatan Tahun 2014.

Rosyadi, M. A. I. (2016). Implementasi Kebijakan Tatakelola Peserta Program Jaminan Kesehatan Nasional Di Jatim. JPAP: Jurnal Penelitian Administrasi Publik, 2(01).

Suryani, A. I., \& Suharyanto, A. (2016). Implementasi Program Badan Penyelenggara Jaminan Kesehatan (BPJS) Dalam Meningkatkan Pelayanan Administrasi Kesehatan di Rumah Sakit Umum Sibuhuan. Publikauma: Jurnal Administrasi Publik Universitas Medan Area, 4(1), 86-99.

Van Meter, D. S., \& Van Horn, C. E. (1975). The policy implementation process: A conceptual framework. Administration \& Society, 6(4), 445-488. 